\title{
THE IMPLEMENTATION OF INTERNATIONAL STANDARDS AND SPECIFICATIONS (ISO-SCUBA) ON IMPROVING THE QUALITY OF DIVING TOURISM IN AQABA, JORDAN
}

\author{
Ibrahim Kahlil BAZAZO \\ The University of Jordan, Faculty of Tourism and Hospitality, Department of Travel and Tourism, Jordan, e-mail: i.bazazo@ju.edu.jo \\ Omar Abedalla ALANANZEH* \\ Yarmouk University, Faculty of Tourism and Hotel Management, Department of Hotel Management, Jordan, e-mail: o.ananzeh@yu.edu.jo
}

\begin{abstract}
Citation: Bazazo, I.K., \& Alananzeh, O.A. (2020). THE IMPLEMENTATION OF INTERNATIONAL STANDARDS AND SPECIFICATIONS (ISO-SCUBA) ON IMPROVING THE QUALITY OF DIVING TOURISM IN AQABA, JORDAN. GeoJournal of Tourism and Geosites, 33(4spl), 1557-1563. https://doi.org/10.30892/gtg.334spl17-608
\end{abstract}

\begin{abstract}
The study aims to identify the impact of applying the international standards and specifications issued by the International Organization for Standardization and Metrology (ISO-Scuba) in enhancing competitive advantages and comparative advantages which improves the quality of diving tourism in the Jordanian Gulf of Aqaba coast. An analysis of all the provisions of international standards and specifications for marine diving tourism is utilized to provide a comprehensive picture of the reality of diving tourism in the study area. The results of the study revealed that the application of ISO standards and specifications in marine protected areas in the Gulf of Aqaba can provide a flexible and adaptable system in managing the quality of tourism services provided to tourists. It contributes to providing a framework for applying international standards and specifications to marine protected areas in the study area. This contribution is critical for decision-maker in adopting the holistic planning process for the diving tourism industry in the city of Aqaba, especially in light of expansion a great diving tourism industry witnessed in Aqaba city since the beginning of this century.
\end{abstract}

Key words: international standards and specifications, diving tourism, tourism quality, competitive advantages, comparative advantages, sustainability of the tourism product.

\section{INTRODUCTION}

The tourism industry is one of the most important economic sectors that leads the global economy at the present time (Bazazo and Alananzeh, 2016). It has a number of patterns and forms and diving tourism is one of the most important patterns of this indu stry during recent years (Izwar et al., 2020; Nordin, 2005). Many reports and international studies, including United Nantion World Tourism Organization (UNWTO, 2019) indicates that the annual growth rate of diving tourism is estimated at $16 \%$, especially in light of the rapid technological progress in marine science, as well as the development of devices underwater photography, which relies on remote sensing techniques, nanosat moons, and artificial intelligence systems (Zhang et al., 2019). This development has led many tourists at the international level to search for attractions for diving tourism, which have the ingredients that provide coral reefs, beautiful marine wildlife, and healthy tourism. The city of Aqaba, which overlooks the Red Sea coast, is one of the richest environments that attracts those looking for diving, snorkeling, and to enjoy all the natural aspects and biological diversity under the water (Deeb et al., 2020; Jawabreh et al., 2020; Chiu et al., 2019, Masa'deh et al., 2019; Alananzeh et al., 2018).

Diving tourism in the Gulf of Aqaba city is considered a dynamic phenomenon with variable properties. The Aqaba Special Economic Zone has witnessed, since the beginning of this century, rapid developments in the patterns of the tourism industry, foremost of which are marine diving tourism. The significant development in the size of diving tourism, and creating structural changes in the structure of diving tourism, and the increasing global demand for this type of tourism has led to the emergence of a new research trend dealing with diving tourism; its importance, and added value. And given the comparative advantage and competitive advantage of the study area, it has become an important tourist attraction at the regional and international levels. Many companies working in the field of the marine diving tourism industry in Aqaba suffer from a lack of application and knowledge of international standards and specifications in the application of quality standards in marine diving tourism and the achievement of public health and safety standards. Quality has become a prerequisite for competition and attracting tourists at the international level (Mukayev et al., 2020; Mukayev et al., 2019; Masa'deh, 2017; Alshawagfih et al., 2015).

In addition to some aspects of the threat to the marine environment, as well as the presence of some deaths, accide nts, and injuries resulting from the failure to apply international standards and specifications in the diving tourism industry. Therefore, it is necessary to establish an integrated system for the quality, marine environment, health, and public safety acc ording to standard specifications in order to improve diving tourism (Coxon et al., 2018, Hughes et al., 2017). This is done by setting the appropriate treatments to bridge the gap between the actual reality and the requirements of the international standards for diving tourism specifications.

This system contributes to motivating companies working in the marine diving industry in the city of Aqaba to apply specifications in terms of quality, environment, health, and public safety. The study is a conceptual framework that addresses the diving tourism industry in the city of Aqaba, in a manner that relies on excellence and uniqueness in providing tourism products according to international standards and specifications, where the tourist has become more aware of the value which creates challenges for tourism products and tourist demands. Thus, the study tries to answer the following questions:

1. To what extent are the tourist companies specialized in diving tourism industry adhering to international standards and specifications related to the quality of marine diving tourism products in Aqaba?

2. What are the most important international standards and specifications used in the marine diving tourism industry?

3. How is the impact of the application of international standards and specifications reflected in enhancing the competitive and comparative advantage of diving tourism in Aqaba?

\footnotetext{
${ }^{*}$ Corresponding author
} 
Accordingly, the study aims to identify the speed of changes and shifts in international standards and specifications in the diving tourism industry and its impact on the city of Aqaba, which did not receive sufficient attention from study and research. The main objective of the study is to include the concept of international standards and specifications for the diving tourism industry with all companies operating in the marine diving industry in Aqaba to improve their environmental, social and economic performance, and then applying for an international conformity certificate. The sub-goals are as follows:

1. Analysis of international systems, legislation, standards, and specifications for the marine diving tourism industry.

2. Providing a practical and theoretical framework on international specifications and standards in the diving tourism industry that contributes the companies in Aqaba to obtaining the quality certificate for international standards for marine diving.

3. Analyze the general system of diving tourism in Aqaba, provide management to protect environmental, cultural and social values, and ensure the sustainable use of marine resources in the Gulf of Aqaba coast, by adhering to international standards and specifications

\section{The Importance of Studying}

The importance of the study lies in identifying the international standards and specifications that are used in the diving tourism industry at the international level, which leads to the availability of a comprehensive thought for the decision-maker in the future planning in a sustainable manner, and to help in giving a clear holistic view of the reality of the diving touris $m$ industry, with the aim of detecting changes that occurred in diving tourism; to take proper measures in enhancing the quality of the tourism product. As diving tourism has become one of the most important elements of coastal environments and has a high added economic value for tourist destinations. The geographical diving environment in the Gulf of Aqaba coast is classified as one of the most important diving sites at the regional and global level especially in light of the growing development in scuba diving tourism. Diving tourism is one of the new forms of tourism which increases its chances of developing it in Aqaba due to the diversity in the marine environment, and due to the comparative advantage and competitive advantage of the study area; which qualifies it to be an important attraction at the regional and international level in the pattern of diving tourism. In addition, the importance of the study stems from the importance of the commitment of companies operating in the marine diving tourism industry in Aqaba to international standards and specifications. These standards are considered as a reference and guide to serve the marine diving industry sector, raise product quality tourism, and upgrading tourism services by setting standards for quality and professional skill and publishing professional training in the field of marine diving to raise the level of workforce performance in the diving tourism industry, and reduce risks and adhere to the principles of public health and safety.

\section{Study Justifications}

The study was based on several justifications, highlighting the need for such research, to fill the void in the literature of tourism management, and to complement what others began to plan and develop the diving tourism industry in the Gulf of Aqaba coast. The process of studying the general system of diving tourism in Aqaba is an important element in developing tourism that has not received enough attention; the majority of studies related to this aspect have been limited to studying limited aspects without reference to international standards and specifications and their impact on the development of the diving tourism industry, and its importance in this field, despite what the study area has in all the various vocabulary of the diving tourism industry development; Which qualifies it to be an important attraction at the international level, with high-quality standards.

\section{Time and spatial framework of the study}

The limits of the study are of three types that control the study process, and they are as follows:

1. Spatial boundaries: represented by the coast of the Gulf of Aqaba, on the Red Sea, which is located in the south of Jordan, $330 \mathrm{~km}$ south of the Jordanian capital, Amman, as shown in Figure 1.

2. The objective limits: Examining the reality of the diving tourism industry in Aqaba, and getting to know all the international standards and specifications in the diving tourism industry.

3. Temporal limits: is to diagnose the reality of the diving tourism industry at the present time, taking into account future expectations and projections.

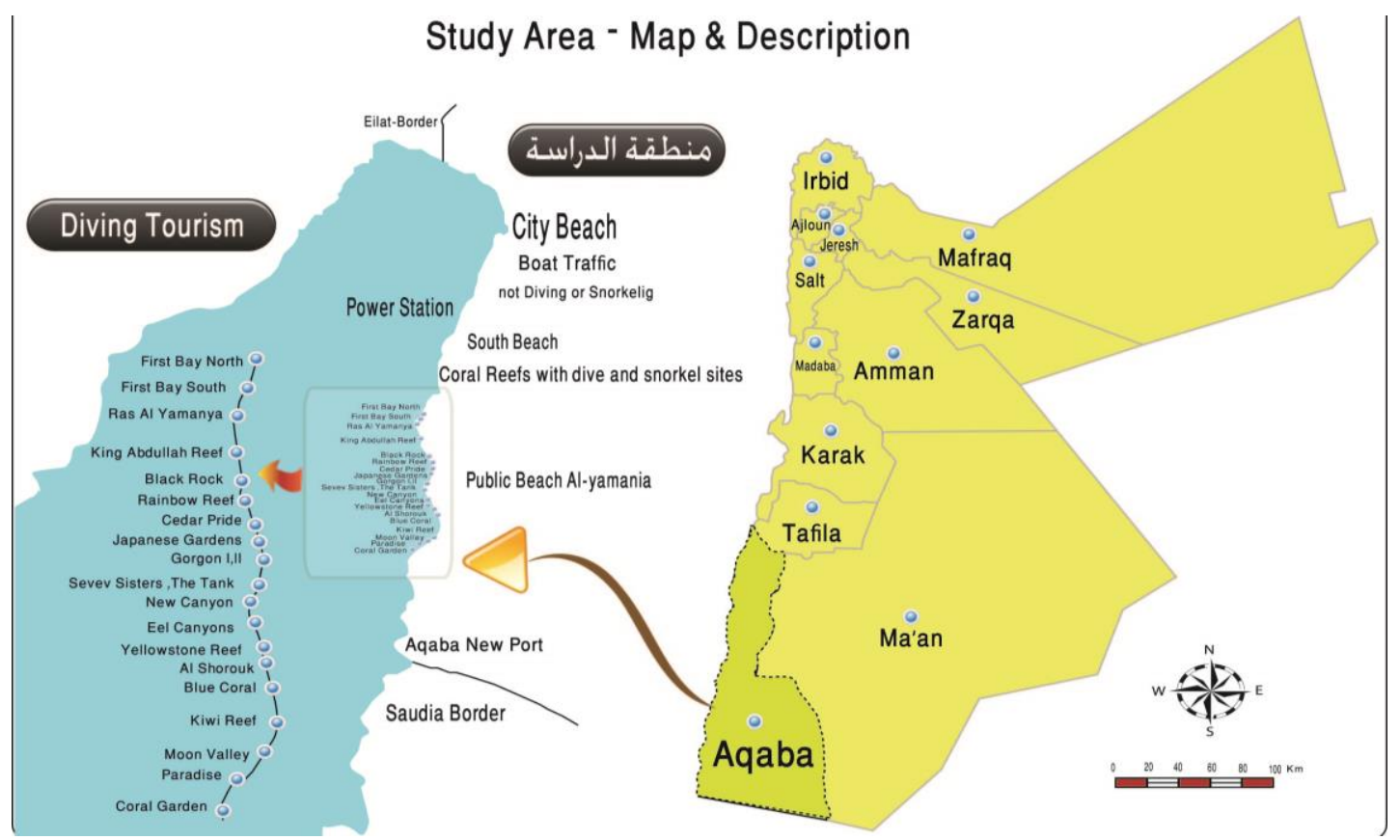

Figure 1. The Coast of Aqaba Gulf, Jordan (Source: Prepared by the researchers using ARCGIS 10.3 software) 


\section{STUDY METHODOLOGY}

The study combines theory and application, as it includes a theoretical framework that addresses the concepts of growth and development of the pattern of diving tourism in the Gulf of Aqaba coast and practical application that contributes to the identification of all international standards and specifications in the diving tourism industry, as a prelude to drawing developmental policies directed to tourism plans in the study area. This requires combining more than one approach at the same time, such as the analytical approach, the organizational approach, and the perceptual approach; In order to highlight the regional personality of the pattern of diving tourism in the Gulf of Aqaba coast, according to the comprehensiveness of the aforementioned approaches. The study relied on the use of a spatial descriptive approach to describe the criterion and standards issued by the International Standards Organization (ISO) for marine diving, and the extent of their applicability to companies operating in the field Diving tourism in Aqaba.

\section{Previous studies}

There are many and varied studies dealing with diving tourism due to the diversity of the nature of these studies and the diversity of interests and specializations that they study (Alananzeh et al., 2018; Mota, 2016; Mustafa, 2012, Cardwell, 2011). Therefore, previous studies that dealt with the topic of the impact of applying the international standards (ISO-Scuba) on improving the quality of the diving tourism industry are characterized by their scarcity at the international level, and not being addressed at the local level. The studies that dealt with the topic focused on natural, economic and social factors without addressing the physiology of international standards, specifications and standards used in the diving tourism industry, and the impact of that on achieving quality standards in to urist services provided to tourists, and the sustainable conservation of marine environments. A group of research has focused on studying the environmental impacts of diving on the quality of marine ecosystems. For example, the study of Thompson et al. (2008) came under the title "ISO 14001: Towards international quality environmental management standards for marine protected areas".

The study relied on an evaluation of environmental management systems in marine protected areas and emphasized the importance of flexible and adaptive administrative systems. It proposed a framework for the application of ISO (14001) in marine protected are as in northern Chile, where ISO was used (14001) as a criterion for evaluating and improving the proposed management plan for the marine reserve in Chile through the application of the best international standards and specifications. While the study of the Royal Life Saving in Australia (Royal Life Saving, 2019), under the title Health and Safety in Scuba Tourism in Australia's shores, confirmed on identifying and analyzing policies, legislations, and standards related to the diving tourism industry by comparing the legislation gover ning diving tourism in Australia and comparing it with international specifications and standards. The study revealed the importance of organizing marine diving tourism in safe environments and achieving quality in providing tourism services.

The study of Chimienti et al. (2019) indicated that marine diving tourism has many impacts on biodiversity, marine life, marine habitats, and landscapes. Therefore, all international standards and specifications must be taken to achieve optimal management in planning and marketing diving tourism especially in fragile ecosystems. It revealed the importance of harmonizing local and international laws and regulations, which contributes to achieving the highest quality standards in providing diving tourism products.

While Anwer and Hamilton (2005) focused on studying recent trends in the diving tourism industry on an international level by focusing on the latest international specifications and standards used in the marine diving tourism industry. They suggested that there are opportunities to improve relations between the diving sector, maritime tourism operations, and those responsible for local governance and management to achieve more sustainable results in the diving tourism industry. Meanwhile, Neto et al. (2020) found that the marine diving tourism industry relied mainly on achieving the highest standards of added value and achieving benefits competitiveness by adhering to international standards and specifications in the marine diving tourism industry, which contributes to many probl ems related to misuse of resources. The study focused on the importance of qualifying workers in the tourism industry in marine diving to achieve sustainable development advantages and the highest quality standards. The discussion of the previous study indicates the necessity of developing an integrated methodological framework that regulates the reality of the diving tourism industry in the Gulf of Aqaba coast in line with the introduction of international specifications and standards; to provide an integrated holistic framework in the process of the marine diving industry in the Jordanian Gulf of Aqaba coast. This study is, as a continuation of the previous studies, an attempt to reveal the nature of diving tourism in the Gulf of Aqaba coast through the holistic approach to all the elements of the subject refe rred to.

\section{STUDY AREA}

Aqaba is the only coastal city in Jordan and its lung on the outside world. Aqaba is located in the southernmost part of Jordan on the coast of the Red Sea. The city is $330 \mathrm{~km}$ south of the Jordanian capital, Amman. The Gulf of Aqaba is characterized by a diversity of ecosystems. In the waters of the Gulf of Aqaba, there are 120 types of hard coral, and 180 types of soft coral (Al-Tawaha et al., 2019). The Jordanian coast overlooking the Gulf of Aqaba is characterized by the presence of rich environments of seaweed within clusters of depth between one to forty meters. Aqaba has a desert climate with warm winters and hot dry summers, which makes it an ideal diving destination throughout the year. Water temperatures reach $26^{\circ} \mathrm{C}\left(79^{\circ} \mathrm{F}\right)$ during the summer and drop to $21^{\circ} \mathrm{C}\left(70^{\circ} \mathrm{F}\right)$ in winter.

The Gulf of Aqaba waters is characterized by a high degree of clarity, due to the lack of marine currents and valleys that flow into the waters of the Gulf of Aqaba. Because of the amazing mix of marine life and coral reefs, water transparency, and the pleasant weather it provides all year round; the Gulf of Aqaba is one of the most beautiful diving areas in the world. The Aqaba coast is divided in terms of morphological formation into three regions distinguished in terms of its sandy content and the topography of the surrounding areas. The northern section in the city of Aqaba with sandy beaches, and is characterized by the presence of seaweed. The second section extending from the central port region to the southern region of the coast, which is characterized by a dense presence of coral reefs, diving tourism activities, and the Military Museum underwater. And the third region is the coarse sandy southern beach, in the southern port area, where there are artificial reefs that have become a site for habitats and diving tourism within new environmental systems, such as artificial marine reef Near the Royal Yacht Club, or ready-to-sink bodies such as Cedar Pride and others. The marine park area on the south shore of the Gulf of Aqaba, a coastal strip with a length of $7 \mathrm{~km}$ and a width of 400 meters, was created in 2017 to preserve the marine environment and biodiversity (The Royal Marine Conservative Society of Jordan, 2016). The morphological uses of the marine park beach are for four main sections: the restricted protected area, Recreation and tourism area, diving and swimming area, and beach area, as shown in figure (2).

The diving tourism industry has become, at the present time, one of the most developed patterns of tourism in the size and trends of tourism movement at the international level due to technological development, methods of underwater photography, the development of early warning systems, public health and safety means, the development of diving equipment. Many international reports indicate, including the World Tourism Organization report for 2019 (UMWTO, 2019), that the growth rates in the diving tourism industry increased by 16\% annually, which indicates the importance of this tourism pattern in achieving economic savings and operating manpower. 
The diving tourism industry in Aqaba has evolved since the beginning of the current century in a tangible and clear way. Aqaba is famous for all the ingredients of the modern diving tourism industry, which is represented by the presence of a rich marine environment, the availability of 27 marine diving centers until 2019, the availability of speed boats and six marine sports centers, as well as the presence of Aqaba within the Golden Triangle, which includes both Petra and the Rum Reserve; contributed to the increase in attracting tourists. Aqaba became an integrated tourism product that meets the desire of tourists coming to Aqaba.

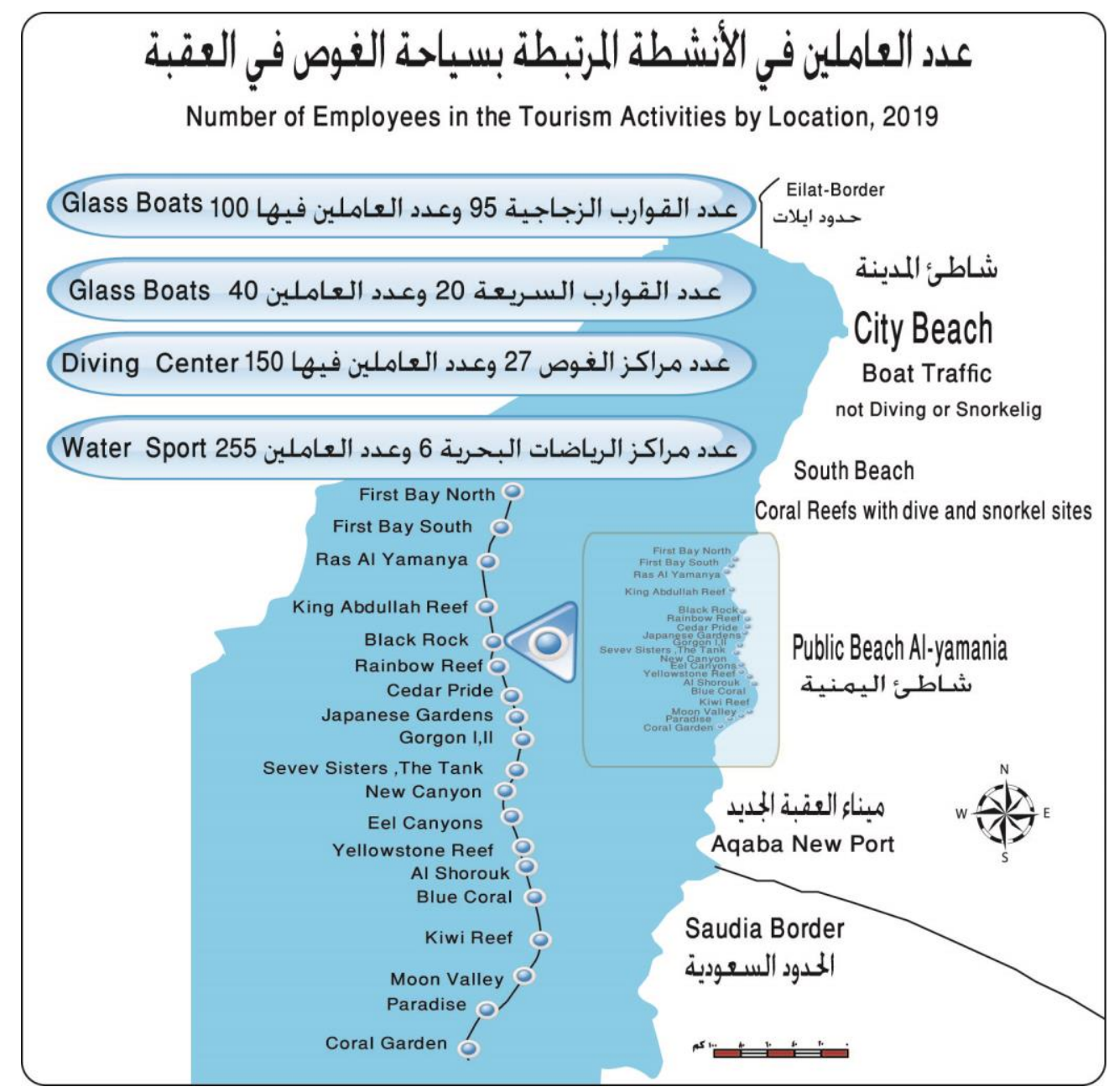

Figure 2. The marine park area of the Gulf of Aqaba (Source: Prepared by the researchers using ARCGIS 10.3)

The diving tourism system consists of a number of elements, which include the marine environment, divers, tourism services, and the host community as shown in Figure (3). The marine environment is one of the most important components of the diving tourism system, which imposes integrated tourism management that takes into account all the items international standards and specifications in a balanced manner, which contributes to achieving sustainable development with the highest quality standards in coastal zone management.

\section{Standard (ISO)}

\section{Scuba Diving Tourism System}

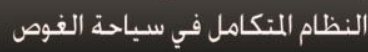

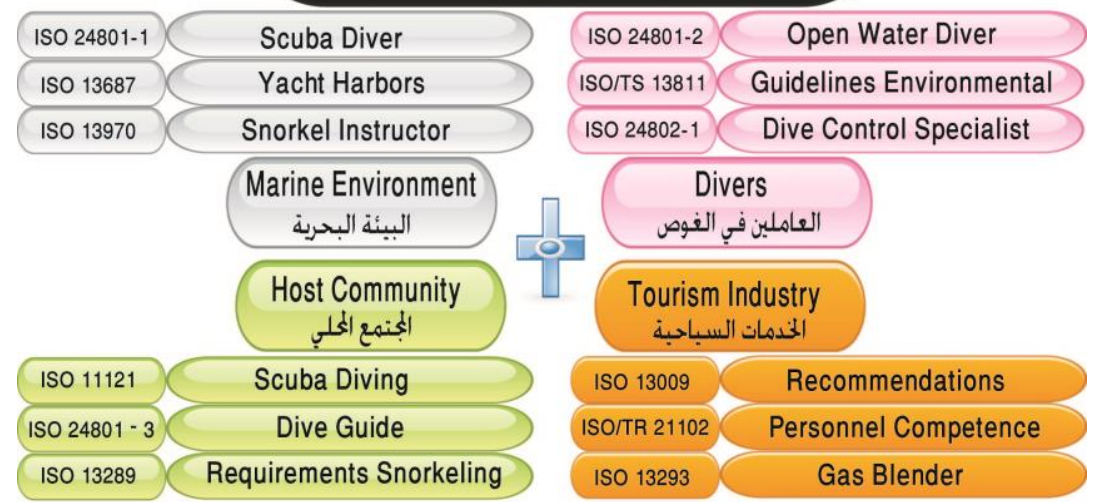

Figure 3. Standard Elements of Scuba Diving System (Source: Prepared by the researchers) 
The concept of diving tourism includes all sightseeing trips whose main purpose is to experience underwater diving and enjoy seeing and photographing all marine creatures such as coral reefs, marine museums underwater, and sunken monuments. The diving tourism industry depends on the tourist coming directly to obtain the service, which is in contrast to other goods that can be delivered directly to the consumer. This rapid growth also presented new perspectives for quality management through the most famous international quality management systems in the diving tourism industry in accordance with international standards, which requires the application of quality management systems that are an important entry point to bring about a fundamental change in the structure of institutions involved in the development and management of diving tourism in the city of Aqaba and on their performance in order to prevail the concept of quality assurance. In light of the increasing competition in the global tourism services market in diving tourism, the importance of the study comes to know the impact of applying international standards and specifications in confirming quality management systems and raising the efficiency of productive performance in diving tourism industry facilities in Aqaba. Emphasizing the importance of companies' commitment in the process of continuous improvement with all inputs of the diving tourism industry in the Aqaba region. Establishing a specialized department whose primary mission is to develop, design, and improve products and services in the diving industry so that they meet the needs of the final consumer, which reflects positively on the development of diving tourism on the international tourism map. And taking the necessity of setting specifications and standards as a priority for all sectors involved in diving tourism in the city of Aqaba; to increase its competitiveness in the regional and global markets and care for the environment in a balanced manner with an interest in quality.

The successive developments in the technical marine diving tourism industry have led to increased competition between the various tourist destinations in the world. Many destinations have adopted the application of international standards for achieving quality as a prerequisite for obtaining a higher market share. Quality was not the only issue of interest, rather, the marine environment and occupational health and safety were an important component for achieving sustainable tourism development in the marine diving tourism industry. Many tourist destinations in many countries of the world have witnessed many threats posed to their marine environments in light of the increasing demand for marine diving tourism, especially the intense competition between tourist destinations that meet the needs of tourists in marine environments characterized by health and public safety, and compatibility with international standards and specifications. Therefore, many of the tourism companies specialized in the field of marine diving tourism have to take into account the environmental aspect in their various activities, functions, operations, and provide tourism products of a high degree of quality. This can only be done through its adoption of international systems, specifications, and standards which reflect a set of procedures and activities to guide companies regarding how to manage the diving tourism process, to achieve various returns, and to improve its performance and quality of its products; thereby ensuring its continuity and survival. The process of continuous improvement of marine diving tourism in Aqaba and maintaining economic competitiveness includes the need to adopt comprehensive quality management strategies based on international specifications and standards in the marine diving industry. Therefore, all public and private sectors working in the marine diving tourism industry in Aqaba must take several ways to improve their job performance based on a comprehensive quality management system, which in recent years has become a necessary condition for the success of the diving tourism industry, and is based on the ISO system for diving tourism in all its types and styles; to achieve leadership and improvement to ensure optimal marketing and planning of the tourism product.

The International Organization for Standardization was founded in 1974 in Geneva, Switzerland. It works to develop international criteria and standards in many different sectors. Recently, the need of many tourist sites interested in developing marine diving tourism to the international standards and specifications has become apparent; for several reasons, the most important of which are: the emergence of many risks in marine diving tourism, chief among them, the emergence of deaths resulting from marine diving errors, lack of familiarity with the marine environment, the emergence of many problems facing the diving tour guide; his lack of knowledge of the changing surface conditions, different water temperatures and visibility, increased depth and lack of direct access to the surface, lack of familiarity with or failure of equipment, inadequate physical and medical fitness, lack of knowledge of dealing with dangerous marine organisms that can cause serious injury or death, as well as risks caused by the nature of boats that are not equipped in a manner consistent with public health and safety regulations. Safe diving requires many international standards and specifications, which have become an indispensable necessity in light of the continuous development in the marine diving tourism industry. Therefore, the International Organization for Standardization (ISO) was keen on setting standards to control all aspects of the diving tourism industry under the requirements of quality, security, and public safety to reduce risks. A series has been developed that includes international standards that define safety and quality requirements for all elements of the diving tourism industry, from training divers and trainers to the equipment and procedures that should be used. The World Tourism Organization (WTO) stressed in its report for 2019 the importance of organizing diving tourism in all countries of the world according to international standards and specifications, which are mainly based on providing public health and safety and maintaining the sustainability of marine tourism environments. Several international reports confirm that within the next few years the ISO series of international standards and specifications in marine diving tourism is expected to be the only way to enter and stay in the tourist markets. When tourists have the opportunity to deal with more than one marine tourism site, it will undoubtedly be preferable to deal with tourist sites that have quality assurance systems in the marine diving tourism industry. The ISO standards and specifications not only describe the details of quality systems but also set basic guidelines for international quality in various parts of the marine diving tourism system. It takes into account and cares about auditing activities to improve the methods of applying the quality standards and its system, which will benefit from improving the quality of tourism goods and services. It also cares and focuses on training workers in marine diving tourism, which is the cornerstone in the application of a system of international quality standards in the diving tourism industry.

Many tourism companies interested in the marine diving industry in the European Union, Australia, and the United States realize that without applying a quality system, they will lose many of their tourism markets. The European Union countries required all companies working in the field of marine diving to obtain ISO certificates for marine diving. Therefore, obtaining ISO certificates is one of the elements of the strength of companies operating in the marine diving tourism industry in Aqaba, which gives tourists and tourist offices exporting tourist groups to Aqaba the confidence, which leads to increased market share, attracting more tourists, improving quality, and reducing costs. Thus, it is the solid foundation for building a comprehensive quality management system and passport for marine diving tourism in Aqaba, through which it can compete and control a large part of the international markets.

The concept of quality in the marine diving tourism industry is defined in accordance with international specifications and standards as the totality of the features of marine environments with its vital diversity, and its ability to meet the needs of tourists with the highest standards of quality and excellence. As for the quality policy, it is defined as the desire and orientation of companies operating in the marine diving industry to quality as formally set by senior management. Quality management is defined as the activities of the overall administrative function that define the quality policy, its objectives, responsibilities, and implementation through means such as quality planning, quality control, quality assurance, and quality improvement within the requirements of marine diving standards and specifications. Quality control is defined as the operational techniques and activities used to meet quality requirements. While quality assurance is defined as all the activities 
that are carried out within the quality system and explained according to the need to secure or to find sufficient confidence that a party will fulfill all the quality requirements. The quality circle is defined as the jobs that are part of the general cycle of the tourism product, and it affects the quality of the tourism product such as inspection, marketing, service, market studies, and product development.

The international organization has issued a series of standards for marine diving tourism management systems that include many social, economic, and environmental elements that are integrated with the requirements of sustainability in marine environments. These systems help tourism companies operating in the marine diving tourism industry to achieve economic and environmental goals in a balanced manner while maintaining public health and safety. Conformity with international standards gives a competitive position to companies operating in the marine diving tourism industry in a more effective, efficient, and flexible manner. Tourism companies in Aqaba represent an opportunity to transfer technology and a source of guidance to neighboring countries in the Middle East and North Africa, and to contribute to achieving the better performance of all operations in the marine diving tourism industry.

The application of quality standards to companies operating in attracting tourists to practice marine diving in the city of Aqaba contributes to many advantages that are positively reflected in the level of companies' performance enabling them to provide advanced tourism products. From this standpoint, the tourist companies operating in the diving tourism industry in Aqaba are required to emphasize this principle and consider it a basis and a goal upon which to structure its business and production. Despite the mystery and difficulties surrounding the ISO systems, tourism companies in Aqaba should be restricted to this system for reasons including that the entire world has become an integrated market and depends on health tourism, enhancing competitiveness in international markets, increasing the attraction of tourists, protecting marine environments from wrong use, creating conditions for new investments, and investment expansion in Aqaba.

Quality in the marine diving industry in Aqaba is a certificate of behavior and culture. Thinking about achieving quality is undoubtedly a strategic decision, and this purposeful thinking pattern is considered a benefit for all public and private institutions and the local community.

The series of international standards for organizing and managing marine diving tourism consists of a number of specifications, the purpose of which is to encourage and develop a more efficient and effective marine tourism management in organizing diving tourism in tourist environments, and to provide useful and practical means which lead to providing a correct basis in directing tourism traffic in proportion to energy capacity for marine environments. Therefore, it is considered a good way to limit the damage to diving tourism sites in marine environments in the early stages of the tourism site's life cycle. The result of this series is to develop Environmental Performance in the diving tourism industry. There are two types of international standards and specifications that are used in organizing and managing the marine diving tourism industry: The American Standards and Specifications, Recreational Scuba Training Council (RSTC) Standards 37) that focus on training and enabling human resources that work in diving in marine tourism environments, and the other type of the international standards and specifications is the ISO systems, which are more comprehensive, with a wider g lobal reach, and based on the requirements of achieving sustainability in marine environments.

There are several international ISO standards for organizing diving tourism according to the goals and objectives related to the organization and management processes as shown in Figure 4, with the aim of improving infrastructure and metadata in diving tourism management in marine environments in two directions: the first is to prepare a guide for sustainable tourism environmental management in Marine environments. While the second is related to the capacity building program for manpower in the marine diving tourism industry. Thus, these international standards meet the sustainable balance between the marine tourism environment and the local community. To achieve this balance, there are four key requirements that include:

1. The general policy and strategy of the tourist site.

2. Planning: It includes environmental issues and legal requirements.

3. Implementation and operation: It includes structure and responsibilities, training, awareness, skills, communications, document control, operational control, emergency forecasts, and feedback.

4. Scanning and Correction Procedures: includes disclosure and measurements, mismatches, correction procedures, and records.

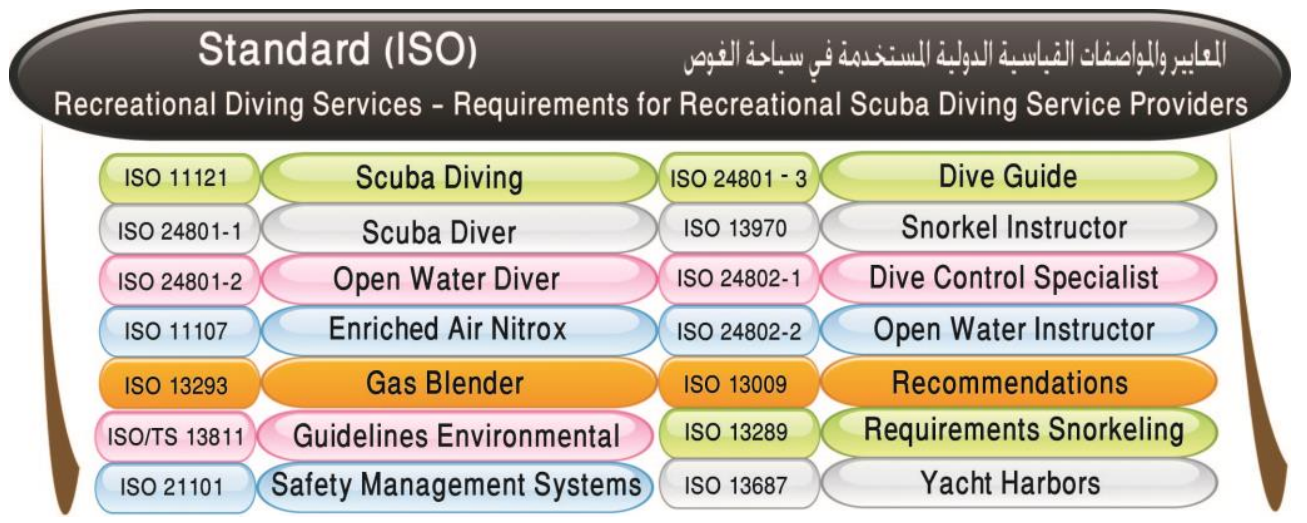

Figure 4. ISO standards for Organizing Diving Tourism (Source: Prepared by the researchers)

\section{FINDINGS AND RECOMMENDATIONS}

The results of the study indicate a clear gap between the current reality of the marine diving tourism industry in Aqaba and the international requirements and standards, which reflects negatively on the volume of tourism movement and the inability to compete at the international level. Diving insensitive and fragile places require effective management to protect environmental, social, and cultural values, promote sustainable tourism development goals, and preserve and avoid tampering with original environments.

The study reached the importance of international standards and specifications in diagnosing and analyzing all variables in the diving environment concentrated in the city of Aqaba in order to reach the highest levels of quality in providing the tourism product, sustainable conservation of the marine environment, and achieving the highest levels of public health and safety in the Gulf of Aqaba coast.

The acquisition of ISO certificates is one of the elements of the strength of companies operating in the marine diving tourism industry in Aqaba, which gives tourist offices in Aqaba confidence and leads to an increase in the market share, attracting more tourists, improving quality, and reducing costs. This study comes with all its concepts related to the diagnosis and evaluation of the general situation of diving tourism in the Gulf of Aqaba coast to be a scientific tool that helps in analyzing the existing situation, in preparation for setting a clear-cut 
strategy to develop diving tourism pattern according to the latest international standards and specifications in the marine diving tourism industry. The study recommends focusing on preserving marine ecosystems in the Gulf of Aqaba coast in line with international data and standards, applying the principles of integrated marine ecosystems management, integrating them into national tourism plans and strategies, working to include areas of coral reef gathering and the Military Museum within the UNESCO natural world heritage system.

The study recommends the need to develop institutional capacity and the national capacity for planners in understanding the $n$ ature of the relationship between the private dynamics of diving tourism, and access to international experiences that have been obtained the ISO certificates. Rehabilitation of special authority in the Aqaba Special Economic Zone Authority to communicate with international donors that grant quality certificates within international standards and standards in diving tourism, and enable diving centers in Aqaba to possess all tools for rehabilitation and follow-up operations. In addition, the need to introduce codes of conduct for workers in the diving industry, provide support for the programs of recreational courses for workers in the marine diving industry, activate health and fitne ss programs and the medical record for workers, and the study recommends the need for future expansion in more detailed studies regarding all components of the diving tourism industry in the study area.

\section{REFERENCES}

Alananzeh, O., Masa'deh, R., Jawabreh, O., Al Mahmoud, A., \& Hamada, R. (2018). The Impact of Customer Relationship Management on Tourist Satisfaction: The Case of Radisson Blue Resort in Aqaba City. Journal of Environmental Management and Tourism, IX, 2(26), Spring. https://doi.org/10.14505//jemt.v9.2(26).02

Alananzeh, O., Al-Badarneh, M., Al-Mkhadmeh, A., \& Jawabreh, O. (2018). Factors Influencing MICE Tourism Stakeholders' Decision Making: The Case of Aqaba in Jordan. Journal of Convention \& Event Tourism. https://doi.org/10.1080/15470148.2018.1526152

Alshawagfih, K.F., Alananzeh, O., \& Jawabreh, O. (2015). The foundation of selecting cultural tourism production in Jordan. European Scientific Journal, 11(29), 198- 2017. https://eujournal.org/index.php/esj/article/view/6333

Al-Tawaha, M., Benzoni, F., \& Eid, E. (2019). The Hard Corals of Jordan Afield Guide. The Royal Marine Conservation Society of Jordan. ISBN: 978-9957-8740-4-9

Anwar, S., \& Hamilton, J. (2005). Tourism into the Future-Towards 2020, and Beyondl. Tourism Recreation Research, 30(3), 77-85. https://doi.org/ $10.1080 / 02508281.2005 .11081489$

Bazazo, I.B., \& Alananzeh, O. (2016). The Effect of Electronic Tourism in Enabling the Disabled Tourists to Communicate with The Touristic and Archaeological Sites Case Study - Jordan. European Scientific Journal, 12(5), 111-128. https://doi.org/10.19044/esj.2016.v12n5p111

Cardwell, K. (2011). Formal, informal, and incidental learning: how recreational-diving instructors achieve competency. In: Midgley W, Tyler M, Danaher, PA, Mander A, Editors. Beyond binaries in education research. Routledge Research in Education. NewYork, Taylor \& Francis, 221-231, ISBN 978-0-415-88512-6.

Chimienti, G., Bo, M., Taviani, M., \& Mastrototaro, F. (2019). "Occurrence and biogeography of Mediterranean cold-water corals," in Mediterranean Cold-Water Corals: Past, Present and Future, ed. C. J. C. Orejas (Springer International Publishing AG), 213-243. https://doi.org/10.1007/978-3-319-91608-8_19

Chiu, L.K., Ting, C., Alananzeh, O.A., \& Hua, K. (2019). Perceptions of Risk and Outbound Tourism Travel Intentions among Young Working Malaysians. Dirasat: Human and Social Sciences 46(1), 365-379.

Cinner, J. (2020). Coral reef livelihoods. Curr. Opin. Environ. Sustain. 7, 65-71. [CrossRef] Grafeld, S., Oleson, K., Barnes, M., Peng, M., Chan, C., Weijerman, M., Divers' willingness to pay for improved coral reef conditions in Guam.

Coxon, C., Dimmock, K., \&Wilks, J., \& (2018). Managing risk in tourist diving: a safety-management approach. In: Garrod, B, Gössling S, Editors. New frontiers in marine tourism: diving experiences, sustainability, management. https://doi.org/10.1016/B978-0-08-045357-6.50014-0

Deeb, A., Alananzeh, O.A., Tarhini,A., \& Masa'deh, R. (2020). Factors affecting job performance: the case of Jordanian hotels' kitchen staff. International Journal of Public Sector Performance Management, 6(3), 340-360. https://doi.org/10.1504/IJPSPM.2020.107766

Hughes, T.P., Barnes, M.L., Bellwood, D.R., Cinner, J.E., Cumming, G.S., Jackson, J.B.C., Kleypas, J., Leemput, I.V.D., Lough, J.M., \& Morrison, T.H. (2017). Coral reefs in the Anthropocene. Nature 546, 82-90. https://doi.org/10.1038/nature22901

Jawabreh, O., Masa'deh, R., Mahmoud, R., \& Hamasha, S.A. (2020). Factors influencing the employees services in hospitality industry case study Aqaba five star hotels. GeoJournal of Tourism and Geosites, 29(2), 649- 661. https://doi.org/10.30892/gtg.29221-496

Izwar, I., Badaruddin, B., Mulya, M.B., \& Sibarani, R. (2020). Potential of Reusam Island to Become Sharia Ecotourism Area. GeoJournal of Tourism and Geosites, 30(2spl), 827-834. https://doi.org/10.30892/gtg.302spl07-511

Masa'deh, R., Alananzeh, O., Jawabreh, O., Alhalabi, R., Syam, H., \& Keswani, F. (2019). The association among employees' communication skills, image formation and tourist behaviour: perceptions of hospitality management students in Jordan. International Journal of Culture, Tourism and Hospitality Research, 13(3), 257-272. https://doi.org/10.1108/IJCTHR-02-2018-0028

Masa'deh, R., Alananzeh, O., Algiatheen, N., Ryati, R., Albayyari, R., \& Tarhini, A. (2017). The impact of employee's perception of implementing green supply chain management on hotel's economic and operational performance. Journal of Hospitality and Tourism Technology, 8(3), 395-416. https://doi.org/10.1108/JHTT-02-2017-0011

Mota, L. (2016). Using Of Natural Spaces For Tourism Activity Scuba Diving And Impacts On Aquatic Animals. The International Journal of Tropical Veterinary and Biomedical Research, 1.1, https://doi.org/10.21157 / IJTVBR.V1I1.5069

Mukayev, T.Zh., Ozgeldinova, O.Zh., Janaleyeva, M.K., Ramazanova, Ye.N., \& Zhanguzhina, A.A. (2020). Assessment of the Tourist Recreation Capacity of Lake Alakol Basin. GeoJournal of Tourism and Geosites, 30(2spl), 875-879. https://doi.org/10.30892/gtg.302spl13-517

Mustafa, M.H. (2012). Improving the Contribution of Domestic Tourism to the Economy of Jordan, Asian Social Science, 8(2), 49-61. https://doi.org/10.5539/ass.v8n2p49

Neto, A., Q., Dimmock, K., Lohmann, G., \& Scott, N. (2020) Destination competitiveness: how does travel experience influence choice?, Current Issues in Tourism, 23(13), 1673-1687, https://doi.org/10.1080/13683500.2019.1641070

Nordin, S. (2005). Tourism of Tomorrow: Travel Trends and Forces of Change. https://doi.org/10.13140/2.1.1422.7849

Thompson, M.H., Dumont, C.P., \& Gaymer, C.F. (2008). ISO 14001: Towards international quality environmental management standards for marine protected areas. Ocean \& Coastal Management, 51(11), 727-739. https://doi.org/10.1016/j.ocecoaman.2008.07.004

Zhang, R., Wang, Z., \& Zhang, Y. (2019). A person-following nanosatellite for in-cabin astronaut assistance: System design and deep-learning-based astronaut visual tracking implementation. Acta Astronautica. 162, 121-134. https://doi.org/10.1016/j.actaastro.2019.06.003

*** Australian Water Safety Council. National Water Safety Plan 2004-2020. Sydney: Australian Water Safety Council, 2004

*** Royal Life Saving Society in Australia. Royal Life Saving National Drowing Report. (2019). www.royallifesaving.com.au/_data/assets/pdf_ file/0003/25833/rlssa-ndr-2019-digital.pdf

*** The Royal Marine Conservative Society of Jordan. (2016). National Guides for Integrated Coastal Zone Management. Retrieved from http://www.jreds.org/portals/0/pdf/Consult.pdf

*** United Nation World Tourism Organization (UNWTO). (2019). The Travel \& Tourism Competitiveness Report 2019 Travel and Tourism at a Tipping Point. http://www3.weforum.org/docs/WEF_TTCR_2019.pdf

*** Queensland Government. 2019 Queensland Scuba Diving \& Snorkelling Report Visitor Activities and Characteristics: Queensland Government. 